\title{
JUURNAL_RU
}

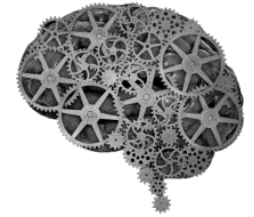

COMPANY GROUP "INTELLEKT"

Тюльнина В.П. Национальный исследовательский технологический университет стали и сплавов Москва, Россия

doi: 10.18411/lj2016-3-81

\section{Пути организации грамматического материала при обучении профессионально ориентированному чтению в неязыковом вузе}

Проблема повышения эффективности обучения студентов неязыковых вузов иностранному языку как средству общения является с позиций компетентностно-ориентированной стратегии профессиональной подготовки специалистов весьма актуальной, ибо уровень владения иностранным языком у студентов неязыковых вузов все еще недостаточно удовлетворительный. Одной из причин этого считается плохое владение грамматикой иностранного языка Значение изучения грамматики состоит в том, что в силу обобщенного характера своих законов она облегчает путь овладения языком, способствует эффективному вхождению в содержание читаемого, развивает логическое мышление учащихся, их способность к анализу и синтезу, то есть играет важную роль в формировании профессиональной компетенции студентов. Актуальной в связи с этим представляется задача нахождения наиболее рациональных путей организации грамматического материала с целью обучения студентов чтению профессионально ориентированной литературы, так как структурные и стилистические особенности научных текстов вызывают специфические трудности в реализации ранее приобретенных грамматических умений и навыков. Целенаправленный подход к обучению грамматике как средству понимания сложных текстов вызывает необходимость специальной систематизации грамматических знаний и приемов работы. Под понятием 
«организация грамматического материала» мы подразумеваем объем и характер сообщаемых сведений для обеспечения высокого уровня сформированности грамматических механизмов, требующихся для выработки профессиональной компетенции [1].

Поскольку существенным и неотъемлемым компонентом чтения является понимание читаемого, очень важно при обучении этому виду речевой деятельности уметь соотнести форму языкового явления с его значением, то есть владеть языковым материалом, в том числе и грамматикой. Большинство исследователей [2], [3] называют три пути сознательного овладения грамматическим материалом: а) самостоятельный анализ; б) коллективногрупповое обучение; в) режим парной работы. Отметим, что самостоятельная работа над грамматическим материалом предполагает самостоятельную аудиторную и домашнюю, выполняемую в режиме самоконтроль, взаимоконтроль или отдаленный во времени контроль преподавателя. Коллективно-групповая работа подразумевает совместную деятельность преподавателя и всех студентов, грамматический материал предъявляется для восприятия непосредственно на уроке. Ее основной принцип - работа преподавателя одновременно со всей группой. Наконец, режим парной работы предполагает умение «сдавать» и «принимать» различные грамматические задания, изученные ранее самостоятельно или при участии преподавателя с использованием или без использования различных средств контроля, например, карточек для парной работы или тестов. В качестве заданий можно предложить следующие:

- отметьте номера предложений, в которых имеются изучаемые грамматические явления;

- выберите правильную форму из множества данных;

- определите и сообщите партнеру количество изучаемых грамматических явлений в приведенном тексте; 
- определите по формальным признакам грамматическое явление, пользуясь приведенным образцом;

- замените грамматическое явление синонимичным (при сохранении адекватности информации);

- ответьте на вопрос партнера, используя приведенный образец и т.д.

Форма и способ презентации изучаемого грамматического материала детерминируется прежде всего степенью его сложности. При этом мы исходим из того, что особое значение в обучении грамматике приобретает принцип функциональности [4], суть которого заключается в том, что в процессе обучения преодолевается разрыв между парадигматикой и прагматикой языка, то есть элементы языковой структуры рассматриваются с точки зрения полезности в речевой деятельности. Это значит, обучению подлежат те грамматические явления, которые наиболее характерны для стиля научной литературы, это значит, функционально - обусловленные. В результате сужается количество грамматических единиц, и, следовательно, внимание сосредотачивается лишь на том, что является доминирующим. Мы считаем, например, что такие грамматические явления в немецком языке как система временных форм действительного залога, двух-, трех- и одночленный пассив, структура простого предложения, склонение существительных могут быть предложены для самостоятельного изучения с последующим облигаторным контролем изученного. Распространенное определение, инфинитив пассив, инфинитивные конструкции и обороты, конструкция «причастие I + zu», структура сложных предложений, модальные глаголы и синонимичные им модальные конструкции вводятся и тренируются в режиме коллективногруппового обучения.

Однако знание грамматических структур, а также значений лексических единиц еще не обеспечивают полного понимания читаемого. Очень важным моментом представляется нам научить студентов воспринимать текст как целое, его композиционную и содержательную стороны. При этом большое значение 
имеет отбор материала, подлежащего изучению, и его профессиональная направленность. Мы не ставим целью освещение вопроса о принципах отбора текстов, способствующих поэтапному формированию механизмов чтения. На наш взгляд, гораздо более существенным является его языковая обработка для адаптирования к реальным возможностям студентов. Тексты могут объединять простые предложения неосложненной структуры с элементарными пропозициями, простые предложения с синтаксически осложненной структурой, с включенными в них причастными оборотами или инфинитивными конструкциями, а также сложные предложения. Так как учебный текст должен строиться на изученном грамматическом материале, упрощение текста осуществляется так, чтобы оно не привело к искажению заложенного в нем смысла. Так, нельзя включать в учебные тексты для первого этапа обучения такие грамматические явления как «причастия II в роли определения» и «распространенное определение», подлежащие изучению на втором этапе обучения. В тексте оригинала подобные грамматические явления заменяются синонимичными. Так, к примеру, предложение: Die beim Bohren in festen Gesteinen entstandenen Schwierigkeiten wurden von unseren Bergingenieuren erfolgreich ueberwunden - необходимо трансформировать для учащихся начального этапа обучения следующим образом: Beim Bohren in festen Gesteinen sind Schwierigkeiten entstanden. Sie wurden von unseren Bergbauingenieuren erfolgreich ueberwunden. Такого рода замены дают возможность сознательно усваивать сложные грамматические структуры и пути их преобразования.

Одной из особенностей современного немецкого языка является увеличение глубины и емкости предложения - наличие развернутых субъектнопредикатных структур. Сложность для понимания представляет, например, большое число субстантивных блоков в одном предложении, несущих вторичную предикацию: Durch Schlaemmenzugaben aus den Veredelungsanlagen koennte auf rekultivierten Flaechen eine Bodenfruchtbarkeit erreicht warden. Двухкомпонентные блоки Schlaemmenzugaben, Veredelungsanlagen, 
Bodenfruchtbarkeit содержат свернутую информацию, для понимания которой восстанавливается их субъектно-предикатная структура: Schlaemmenzugaben = wenn Schlamm zugegeben wird...; Veredelungsanlagen = die Anlagen, die zur Veredelung dienen...; Bodenfruchtbarkeit = Boden, der fruchtbar ist.

Предметом сложного восприятия для студентов являются и блоки вторичной предикации « прилагательное + существительное» или «причастный оборот + существительное»:Das Magma steht unter dem ungeheurem Druck der auf ihm lastenden maechtigen Gesteinsmassen. Предложение может быть структурировано следующим образом:Das Magma steht unter dem ungeheuren Druck der maechtigen Gesteinsmassen. Sie lasten auf ihm. Коммуникативный план текста при развертывании в обоих предложениях не нарушается.

Характерной особенностью при работе над языком научной прозы является компрессия информации, содержащейся в коммуникативно насыщенных предложениях, с целью их упрощения. Расчленение предложения возможно в том случае, если в обеих его частях сохраняется синтаксическое ядро.Например, предложение Nachdem der Zug unseren Blicken entschwunden ist, erkennen wir immer deutlicher den Aufbau eines Grossgeraetes может быть разделено на две части: Der Zug ist unseren Blicken entschwunden и Danach erkennen wir immer deutlicher den Aufbau eines Grossgeraetes.

Основным условием подобной сепаратизации является потенциальная автосемантия главного предложения: в его состав не должны входить корреляты или лексико-грамматические индексы. Безусловно, при этом происходит ослабление подчинительной связи между главным и придаточным предложением, но семантико-синтаксические отношения и модальность не нарушаются.

В заключение хотелось бы подчеркнуть, что могут быть использованы любые формы и способы предъявления грамматического материала в зависимости от характера грамматических явлений, их особенностей, цели обучения на конкретном этапе и контингента обучаемых. Главным условием 
всякого рода грамматических замещений в тексте оригинала, развертывания и свертывания пропозиций является сохранение семантической эквивалентности оригинального и адаптированного текста и подтверждение общности их коммуникативной задачи

\section{Литература}

1. В.П.Тюльнина, А.Г.Рудакова, К проблеме формирования грамматических навыков и умений при обучении устной речи в неязыковом вузе. Сборник научных статей III Международной научно-методической конференции « Иностранные языки и инновационные технологии в образовательном пространстве технического вуза. Новочеркасск, 2009,с.129.

2. Москальская О.И. Грамматика текста. М., 1981, с.149.

3. Ляховицкий М.В. Методика преподавания иностранных языков. М., 1981, c. 140

4. Абакумов Н.Н. Особенности овладения грамматическими формами английского глагола при дистанционной форме обучения. Сборник научных статей III Международной научно-методической конференции «Иностранные языки и инновационные технологии в образовательном пространстве технического вуза. Новочеркасск, 2009,с.134. 